\title{
Working
}

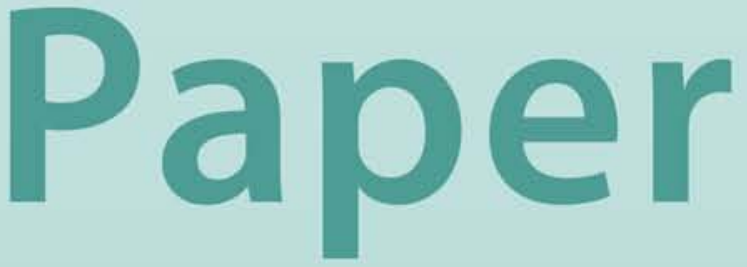


Systemic Weaknesses of Budget
Management in Anglophone Africa

Ian Lienert and Feridoun Sarraf 


\title{
IMF Working Paper
}

Fiscal Affairs Department

\section{Systemic Weaknesses of Budget Management in Anglophone Africa}

\author{
Prepared by Ian Lienert and Feridoun Sarraf ${ }^{1}$ \\ Authorized for distribution by Jack Diamond
}

December 2001

\begin{abstract}
The views expressed in this Working Paper are those of the author(s) and do not necessarily represent those of the IMF or IMF policy. Working Papers describe research in progress by the author(s) and are published to elicit comments and to further debate.
\end{abstract}

This paper examines the merits of the British budget management system that was inherited in Anglophone African countries and which has changed substantially in the United Kingdom since the 1960s. It considers whether the disappointing budgetary performance in Africa is due to weaknesses in the inherited British system, other external influences, or domestic developments. It finds that all three factors have played a role in the widespread problems with budget management systems. Reforms in institutional arrangements are needed, especially in budget execution. Technical reforms will be ineffective unless there are concomitant changes to enhance accountability, improve governance, and increase compliance.

JEL Classification Numbers:E62, H11, H30, H50, H61, N47, O23, P51

Keywords: systemic, Africa, British, budget institutions, budget preparation, budget execution, government expenditure, arrears, audit

\section{Authors'E-Mail Addresses: ilienert@imf.org: fsarraf@imf.org}

\footnotetext{
${ }^{1}$ The authors would like to thank colleagues in the Fiscal Affairs Department, particularly Messrs. Potter, Allan, Brumby, Craig, Diamond, Fournel, Hansen, Jung, Khemani and Schiller for comments on earlier versions of this paper. All remaining errors are our own.
} 


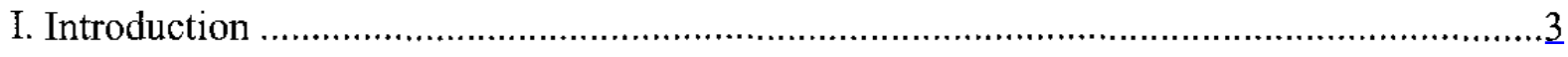

II. Institutional underpinnings of Public Expenditure Management Systems .........................

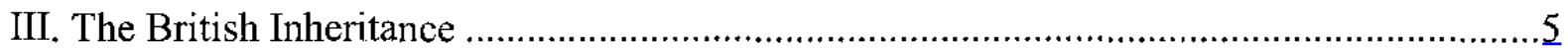

IV. Influence of Donors on PEM Systems ..................................................................

V. Domestic Influences on Public Expenditure Management systems .............................10

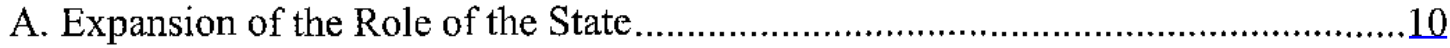

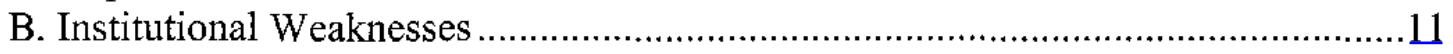

C. Weakness in Budget Preparation............................................................... 14

D. Shortcomings in Budget Execution.............................................................16

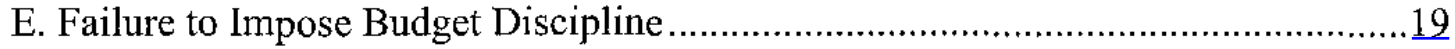

VI. Concluding Remarks and Orientation of Future Reforms .....................................21

Box. Recommendations of the Plowden Commission (1961) ........................................

Table. Domestic Expenditure Arrears in Selected countries, 1999-2001 .........................18

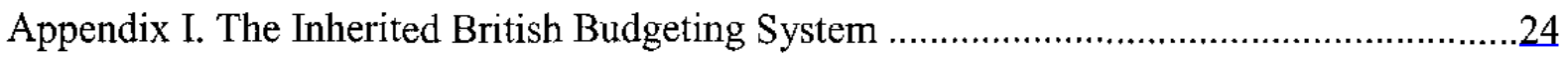

Appendix I Table

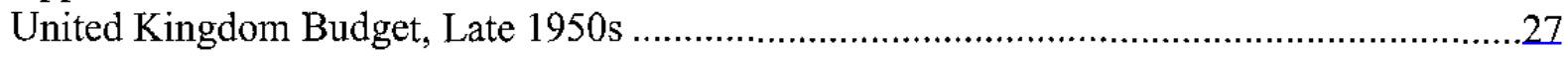

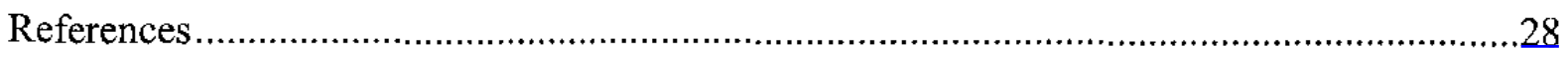




\section{INTRODUCTION}

The public expenditure management (PEM) systems of Anglophone African countries ${ }^{2}$ have a number of weaknesses in both budget preparation and budget execution. Even in recent years, in several countries spending has taken place without budget authority, commitments have been made but cash has not been available for payment, data in accounting ledgers and monthly reports have not been maintained, and long delays have been experienced in preparing and auditing the annual accounts of government.

Because of such weaknesses, budgetary performance has been disappointing. Over the past 20 years or so, planned budget deficits have often been exceeded, for four main reasons: 1) revenue projections have been optimistic, and as a result, budgeted expenditure programs have been predicated on revenues that did not materialize; 2) specific expenditures in the annual budget have been underbudgeted for certain items, especially government purchases of utilities such as telephone, electricity, and water; 3) expenditure control has been poor, leading to domestic expenditure arrears; and 4) there is a general lack of budget discipline.

These developments could be attributed to some combination of: 1) the inherited British system, 2) other external influences, notably those coming from the international financial community, or 3) the manner in which PEM systems have evolved and are operated today in these countries. The extent of these influences is examined in this paper, which first examines the institutional underpinnings of an ideal PEM system (Section II). The key features of the inherited British PEM system and other external influences on the PEM system in anglophone Africa over the past 30-40 years are then examined (Sections III and IV, supplemented by Appendix I). The main domestic influences on present PEM systems and a summary of the major weaknesses in institutional arrangements, budget preparation and budget execution are examined (Section V). Section VI concludes and presents the main directions for future PEM reforms in Anglophone Africa.

\section{Institutional underpinnings of Public Expenditure Management Systems}

\section{Objectives of PEM systems}

The fundamental objectives of sound PEM systems include: (1) securing aggregate fiscal discipline-especially that outcomes for budget deficits and aggregate expenditures are close to the projections made in the approved budget; (2) allocating resources to sectoral programs; and (3) efficient use of resources in attaining the objectives of expenditure programs.

\footnotetext{
${ }^{2}$ Former British colonies in sub-Saharan Africa.
} 


\section{Characteristics of good PEM systems}

The good PEM system is one that has the most satisfactory institutional arrangements to attain the best results relative to the above objectives. In this regard, important institutional factors include: (1) a clear legislative basis for budgeting, with easy-to-apply rules that are fully adhered to; (2) a coherent macroeconomic and budget framework, appropriately classified; (3) a comprehensive budget - no extrabudgetary activity; (4) a powerful central ministry to ensure budget discipline, including accurate costing of expenditure activities (if more than one central agency exists, close collaboration at the central level is a prerequisite); (5) formal constraints on budget deficits and expenditures; (6) adequate technical capacity in parliamentary committees, central agencies of the executive, and spending ministries, including the capability to compare the costs of competing expenditure policies; (7) an effective accounting system that produces timely and quality fiscal reports; (8) functioning audit arrangements to ensure compliance to financial regulations and effective management by spending ministries; (9) mechanisms for handling uncertainty and economic shocks such as shortfalls in revenues, grants or other financing, or unexpected expenditure pressures; (10) civil service salaries that are adequate to retain skilled staff (especially of budget managers, accountants, etc.). A good PEM system also requires fully satisfactory accountability and transparency arrangements, particularly those that emphasize clarity of roles; public availability of budget information; open budget preparation, execution, and reporting; and independent assurances of integrity. ${ }^{3}$

\section{Striving toward the best PEM system}

No country in the world has attained an ideal PEM system. Indeed, views of what constitutes and "ideal" system are continuing to change over time - the budget reforms of recent years in OECD countries attest to this. Nonetheless, there is a general consensus that the objectives of PEM systems have to be clearly defined, and the institutional structures and accountability arrangements to achieve those objectives are broadly as indicated above.

Since the mid-1980s, the United Kingdom itself, as well as non-African former British colonies (e.g., Australia and New Zealand), have radically changed the institutional arrangements of their budget management systems and introduced formal systems of accountability and transparency. These reforms have generally resulted in improved macro-fiscal performance, more rationally determined allocation of resources, and noticeable increases in the value-for-money of public spending. Although other non-African former British colonies (e.g., India, Sri Lanka) may not have undertaken such radical reforms, nonetheless there has been significant modernization of their PEM systems.

In Anglophone African countries, the changes over the years have rarely resulted in the achievement of the above desirable objectives of well-functioning PEM systems (section $\mathrm{V}$ below provides details). Typically, budget deficits have been overrun by $1 / 2$ to 1 percent of

\footnotetext{
${ }^{3}$ These principles are embodied in the IMF's Code of Good Practices in Fiscal Transparency. See www.imf.org.
} 
GDP. ${ }^{4}$ Moreover, there has been a generalized lack of transparency and accountability ${ }^{5}$ and corruption is widespread. ${ }^{6}$

It is beyond the scope of this paper to consider how PEM systems have been influenced by better or worse conditions for overall macroeconomic performance. This is an important consideration, as some non-African countries are less subject to sharp fluctuations in the terms of trade, exchange rates, or other external shocks such as shortfalls in projected budgetary support from abroad. The focus in this paper, however, is on institutional and technical aspects of PEM systems in Anglophone Africa.

\section{THE BRITISH INHERITANCE}

Nearly all countries in Anglophone Africa inherited a British institutional setup and budget procedures (Liberia is an exception). After briefly reviewing key features of the inherited British system (see Appendix I for a fuller description), this section focuses on the main unfavorable features of the British PEM system prevailing in the years when Anglophone African countries were gaining their independence from the colonial power.

\section{Summary of U.K. PEM system in late 1950s}

Although budget laws were relatively unimportant in the United Kingdom, ${ }^{7}$ after independence, the former colonies adopted Public Finance Acts and detailed implementing regulations based on the system prevailing in the U.K. at that time. These specified responsibilities of the key "players" and the various rules for budget management. With regard to budget preparation, the Ministry of Finance's (MOF's) ${ }^{8}$ annual expenditure estimates were: (i) cash-based; (ii) weakly linked to revenue estimates; (iii) incremental — based mainly on percentage increases from the previous year; and (iv) detailed by line-items. For budget execution, the heads of spending agencies ("accounting officers") were responsible for implementing the budget, ensuring compliance with treasury instructions, which were not particularly transparent in the

${ }^{4}$ For details of fiscal performance in Anglophone African countries, see for example IMF (1998).

${ }^{5}$ See Campos and Pradhan (1996) for justification of these assertions.

${ }^{6}$ Four Anglophone Africa countries- Kenya, Nigeria, Tanzania, and Uganda-were in the bottom 14 places of Transparency International's 2000 Corruptions Perceptions Index (see www.transparency.de/).

${ }^{7}$ See Chapter 5 of Premchand (1983).

${ }^{8}$ Ministry of Finance (MOF) is used generically in this paper. In the United Kingdom, the MOF is referred to as "The Treasury". In Anglophone Africa, the "Treasury" usually refers to the unit of the Accountant General's Office of the MOF that performs trcasury functions. 
U.K. ${ }^{9}$ The "above-the-line" transactions (central government revenues and recurrent expenditures--see Appendix I) were comprehensive and passed through a consolidated fund.

The budget system was based on the supremacy of Parliament over the Executive. Parliamentary committees in approving the budget played particularly important roles. The Controller and Auditor General (C\&AG) was also a powerful institution for ensuring the probity of fiscal management.

\section{Unfavorable inherited features of the British system}

At the time of independence of Anglophone African countries, the main weaknesses in the British budget management system included:

- The approved annual budget was prepared mainly on the basis of detailed "bottom-up" estimates. "Top-down" limits on total spending were soft, leading to expenditure creep.

- A dual budget was presented: an above-the-line account showing revenues and mainly recurrent expenditures, and a below-the-line (BTL) account showing "extrabudgetary" interest and net lending to nationalized industries and local governments (which implemented the central government's investment plans). ${ }^{10}$

- Accounting and classification systems were rather basic; deficit financing of the consolidated budget was unclear; and transactions between the central government, local governments and nationalized enterprises were not transparent.

In the U.K. itself, the main weaknesses of the then PEM system were identified by the Plowden Commission (Box 1). Most of the Commission's recommendations were implemented in the U.K. during the 1960s. ${ }^{11}$ Also, action was taken to implement the Plowden Commission's proposals to improve overall management in spending ministries, which was to be elevated to have an importance equal to policy advice (to Ministers) and financial control. Since the beginning of the $1980 \mathrm{~s}$, there has been an acceleration of further reforms in these and other aspects of PEM systems, not only in the U.K., but also in some non-African countries with a British inheritance. $^{12}$

\footnotetext{
${ }^{9}$ In 1958 , the parliamentary Estimates select committee, which did not have access to Cabinet papers, declared on the treasury control system to be "a complex of administrative practices grown up like a tree over centuries, natural rather than planned, empiric rather than theoretical". See chapter 1 of Clarke (1978).

${ }^{10}$ See Appendix 1. The BTL account used by the U.K. at that time differs from "below-the-line" concepts adoptcd when defining the balance of government operations and how deficits are financed (see, for example, IMF (2000)).

${ }^{11}$ See Clarke (1978) for the successes and difficulties experienced.

${ }^{12}$ It is outside the scope of this paper to examine the fundamental reforms that have taken place in the United Kingdom, Australia and New Zealand, for which a large literature exists.
} 
As will be seen in section $\mathrm{V}$, some of the reforms recommended by the Plowden Commission in 1961 are still quite relevant for Anglophone African countries today. For example, only in a few countries are medium-term expenditure frameworks (MTEFs) fully operational; classification and accounting systems still need revamping, and institutional changes to improve collective decision-making are needed. Another serious defect of the inherited British system identified by the Plowden Commission was that "the traditional system of decision-making can no longer be expected to be effective in containing the growth of expenditure within whatever limit the Government has set" (see page 6 of Plowden (1961)). This also has plagued many Anglophone African countries.

\section{Box. Recommendations of the Plowden Commission (1961)}

To address the various weaknesses of the PEM system used in Britain in the early $1960 \mathrm{~s}$, the commission recommended the following strategy for improvement:

- introduce a medium-term planning framework, through surveys of longer-term spending needs;

- instill as much stability in public spending as possible, with due regard for economy and efficiency in the entire public sector;

- improve the tools for measuring and handling expenditure problems, including simplification of classification and accounting systems;

- introduce new arrangements for taking collective decisions and for ensuring that Ministers bore collective responsibility.

One factor responsible for these adverse developments in Anglophone Africa is the absence of the necessary preconditions for successful implantation of the U.K. PEM system. Two such preconditions usually did not exist in Anglophone Africa:

- Well-functioning institutions that followed clearly specified rules. African countries did not rely on a functioning Parliament (with its various committees), an effective external Audit Office, and responsible spending ministries that were capable of managing the budget according to well-defined rules.

- Macroeconomic and revenue stability. Terms of trade fluctuations and revenue collections in sub-Saharan Africa proved to be volatile, making it difficult to introduce 
greater stability in expenditure planning (one recommendation of the Plowden Commission).

\section{INFLUENCE OF DONORS ON PEM SySTEMS}

Most African countries turned to international financial institutions and bilateral donors to provide direct or indirect financing of fiscal deficits, usually for long periods of time, resulting in aid- and financing-dependence. Borrowing from such institutions was necessary since there was not a developed domestic market for government securities (though in the past decade or so, domestic securities markets are developing), nor access to international financial markets. In providing financing, the international community was in a position to exercise considerable influence on PEM systems, both for budget preparation and for budget implementation.

\section{International Monetary Fund}

To achieve macroeconomic policy objectives, strict fiscal deficit targets were established in IMF programs. Net domestic bank credit to government (NDCG) from the banking system was often a key quantitative benchmark in IMF programs. Being derived from the monetary accounts, the deficit-financing targets of fiscal deficits were necessarily on a cash basis. IMF programs stimulated the production of timely fiscal data to allow regular monitoring. However, although the accounting regulations required a simple commitment recording system, in practice most countries limited their recording of transactions to those on a cash basis. As a result, expenditure arrears (overdue unpaid commitments) were not recorded either, even though IMF programs encouraged the monitoring of expenditure arrears.

To attain NDCG targets, in the 1990s the IMF encouraged cash rationing systems, to counter the earlier experiences of monetary financing of fiscal deficits that had led to high inflation in several countries. These cash rationing schemes were a mixed blessing: on the one hand, they contributed to the significant slowdown in inflation in some countries, including the Gambia, Lesotho, and Uganda (where inflation had exceeded 100 percent in the late $1980 \mathrm{~s}$ ). ${ }^{13}$ On the other hand, the cash rationing schemes were not transparent, and arbitrary cuts in expenditure were made to the detriment of efficiency resource allocation. On a more positive note, the IMF provided technical assistance to assist countries to put in place better budget execution and reporting mechanisms (improving expenditure control, introducing better budget classification and accounting systems, etc.).

\section{The World Bank and other multilateral organizations}

The World Bank's influence in shaping PEM systems has also been considerable, particularly concerning capital outlays and the management of aid for budgetary purposes. In the 1980s, traditional Work Bank project-based lending was replaced by a Public Investment Program

${ }^{13}$ See IMF (1997). 
(PIP) approach, an instrument that the Bank actively promoted. One unfortunate consequence of PIPs was their perpetuation of "the dual budget, which may well be the single most important culprit in the failure to link planning, policy and budgeting, and poor budget outcomes". ${ }^{4}$ The Bank also attempted to influence the size and composition of the government salary bill through civil service reforms (CSRs). However, performance of CSRs has at best been mixed (see Nunberg-1997). The Bank also assisted governments in policy analyses via Public Expenditure Reviews (PERs) and better budget resource allocation in the context of medium-term expenditure frameworks (MTEFs), whose aim is to achieve better performance at three levels: macroeconomic stability, sectoral allocation and efficiency of service delivery. ${ }^{15}$ However, it is only recently that in some of these countries that PERs have been seen as fully "owned" by national governments. Also, three-year MTEFs have sometimes been introduced prematurely, in the sense that annual budget outcomes and monitoring mechanisms were still quite primitive, resulting in outer-year scenarios that were inconsistent with actual budget outcomes and/or the macroeconomic framework. More recently, the Bank (and other donors) has been promoting performance-oriented budgeting and the use of computerized Integrated Financial Management Information Systems (IFMISs). Clearly it is desirable to implement MTEFs, performanceoriented budget and IFMISs in the longer term. However, at times their beneficial impacts have been overemphasized, especially when the institutional capacity to introduce, let alone sustain, such all-encompassing reforms, has been limited in many of these countries.

The UNDP was active in financing technical assistance for both improving human and physical capital (often via resident experts or purchase of computers). In providing financial assistance, the EU is also becoming increasingly active in sub-Saharan African countries, particularly in attempting to reorient outlays towards the crucial social sectors.

\section{Bilateral donors}

The main bilateral influence was through donor-financed projects, for which donors usually required governments to keep earmarked funds in special bank accounts outside the consolidated government bank account. Payment procedures were often tedious, adding complexity to aid management. In particular, donors often by-passed the budget process, undermining the objective of comprehensive government expenditure coverage. Bilateral projects were often subject to political considerations, particularly prior to the 1990 s when worldwide strategic alignments were different from today. In the context of donor-funded projects (e.g. for computerization), goods and services were often required to be purchased from donors' markets. On the positive side, several bilateral donors are now helping to modernize PEM systems and improving the operations of institutions (e.g., the U.K. is actively improving audit agencies in Anglophone African countries).

\footnotetext{
${ }^{14}$ For this auto-critique, see Box 3.11 of World Bank (1998).

${ }^{15}$ For a full description, see World Bank (1998).
} 
From the above survey, it is clear that the international community has influenced PEM systems considerably. Some of these influences have dissipated over time. Others are becoming the new "fashions" for reform. As general lessons from the past, it is noteworthy that: (i) technical assistance programs were not always fully institutionalized; (ii) there was often weak political support for implementing PEM reforms; (iii) insufficient training was given to local civil servants; (iv) there was persistently weak implementation capacity (skilled civil servants quit for higher salaries); (v) insufficient domestic budget provision were provided to maintain information systems (especially computers) once foreign financing was withdrawn; (vi) adverse political developments, including military coups and civil wars; and more recently (vii) AIDsrelated deaths of trained staff that directly affect PEM capacity. ${ }^{16}$ Most of these factors are domestic, which are now examined in greater detail.

\section{Domestic Influences on Public Expenditure Management systems}

An early influence on Anglophone African countries' PEM systems was the rapid expansion of the role of the State. Institutions were adapted or created to meet the aspirations of a powerful Executive. Over time, there was a breakdown of budget discipline, leading to increasing laxity in the application of desirable procedures for budget preparation and, especially, for budget execution.

\section{A. Expansion of the Role of the State}

After independence, the state rapidly expanded its role in economic activity. To support this, the civil service burgeoned until the mid-1980s and real civil service wages often fell drastically. ${ }^{17}$ As a result, managers of PEM systems became demotivated, leading to deterioration in the quality of budget management systems. In addition, low salaries contributed to the growth of opportunistic corruption in the expenditure process, which was generally tolerated: malpractice at higher levels of economic and political management was usually not restrained. This was not helped by the weakening of the audit function (see below).

Government investment was channeled through public enterprises, most of which received explicit or implicit budgetary subsidies and capital transfers. Over time, public enterprises became an increasing burden on public finances. However, the cost of public enterprise intervention was not easily identified in the inherited accounting mechanisms. Nor were public enterprises required to be fully accountable for their financial transactions. Although privatization is now taking place, the withdrawal of the State from commercial activities has not been so rapid as in the U.K. itself (especially, in the 1980s).

\footnotetext{
${ }^{16}$ Several of these issues are discussed in Hoover and McPherson (1999).

${ }^{17}$ For example, in Tanzania the civil service more than doubled in size between 1970 and 1985 , but real wages fell by 70 percent over the same period. Sce Stevens (1994).
} 


\section{B. Institutional Weaknesses}

\section{Little change in legal framework}

Most Anglophone African countries developed a solid legal basis for public expenditure management. In some countries, the laws, rules and regulations have been updated and supplemented. However, in several cases the legal framework is largely oriented toward a compliance and control framework of line-item budgeting. Although in some cases they are being adapted to include features of recent developments in modern budgeting, ${ }^{18}$ the legal framework usually provides adequate procedures for budget preparation, expenditure control, fiscal reporting, and auditing. For example, commitment recording and reporting, which is essential for securing expenditure control, is found in the underlying legal provisions. The more urgent need is not to re-write existing legislation, but to ensure that there is adherence to existing provisions.

\section{Weakened role of the legislature}

After independence, strong presidencies often evolved, usually in the context of a one-party political system or a military regime. The executive acquired considerable powers in budget making and without the supremacy of Parliament in budget decision-making (as in the inherited U.K. system), resource allocation was increasingly determined with little debate in Parliament (if it existed). The powerful ministries that supported the strong Executive were often favored in budget resource allocation; regional or ethnic considerations also played a role in some countries.

Some studies for OECD countries have concluded that fiscal performance is better when budgetary authority is focused in the executive (e.g., Alesina and Perotti (1996)). However, it is doubtful whether the findings of this research can be applied in the African context-the "initial conditions" are totally different. These include: the effective powers invested in executive agencies (the Presidency, Cabinet, MOF), the respect of the budgetary rules, and the functioning of parliamentary democracy (in several countries efforts towards democratically elected parliaments to replace one-party states or military regimes are either quite recent or are still in process). Moreover, even in OECD countries, there is an ongoing debate in the literature as to the relationship between fiscal and political institutions and fiscal outcomes. ${ }^{19}$

\footnotetext{
${ }^{18}$ For example, Tanzania adopted a new Public Finance Act in early 2001, which embodies the concepts of outputoriented budgeting. However, it is unclear how this approach will be implemented with the existing PEM system.

19 For example, Skilling (2001) argues that an important source of variation in debt accumulation in OECD countries is due to coordination failure between spending ministers who are more profligate in good times than bad times. Previous research emphasized invariance (procyclical fiscal policy).
} 


\section{New institutions were created to support the strong executive}

The inherited dual budgeting system evolved into a "recurrent budget" and a "development budget." New institutions were created to prepare the two independent budgets: the recurrent budget (which was entirely domestically financed) was prepared in MOFs, whereas new Planning Ministries were created to prepare and implement the development budgets (which were mostly foreign financed). Frequently, these two ministries distributed separate budget circulars. Lack of coordination between the MOF and Planning Ministry may also have reflected differences between the Minister of Finance and the Minister of Plan(ning) and/or the President who, in some cases, exercised de facto control of investment decisions. ${ }^{20}$ In this setting, it was not easy to introduce consolidated budget presentation and classification systems. Moreover, unforeseen recurrent costs evolved from the expansion of investment projects. ${ }^{21}$ More recently, new institutions have been created (e.g., anti-corruption commissions) or existing institutions for effective budget management have been strengthened (e.g., audit office, courts), sometimes without fully considering the budgetary costs of operating them.

\section{Fragmentation within the MOF}

In implementing the budget, rivalries often arose between the accountant general's (AG's) department and the rest of the MOF, ${ }^{22}$ where the functional requirements were also fragmented in several cases. First, instead of acting cooperatively, different departments struggled to take the dominant position, especially if cash could be manipulated. For example, in some countries, there was rivalry for control of the cash-rationing systems put in place in the 1990 s, as there was scope for kickbacks in return for "appropriate" allocation decisions. Second, departments handle debt and aid (often separate), and these are not well integrated with the AG's core accounting responsibilities. Third, those responsible for payroll management often did not coordinate closely with personnel managers (either in line ministries, or in a dedicated central civil service ministry), resulting in poor control of the wage bill and the presence of "ghosts"-fictitious government employees. ${ }^{23}$ Finally, a strong macro-fiscal analysis department was usually missing. One consequence of this was that tax forecasting was left to the revenue collecting agencies, rather than developing this capacity in a macro-fiscal unit of the MOF.

\footnotetext{
${ }^{20}$ In some countries, although the Minister of Finance may have presided the Planning Commission, the Commission was directed from the Presidency.

${ }^{21}$ See, for example, Heller and Aghevli (1985).

${ }^{22}$ In some countries, the Accountant General's Offices were separately from the MOF, whereas in other countries they were integrated in the organisation of the MOF.

${ }^{23}$ See Lienert and Modi (1997).
} 
Fragmentation within the MOF resulted in a number of shortcomings. ${ }^{24}$ First, there was often an unsatisfactory flow of information or development of parallel reporting systems. Since the AG's department records were often not useful for MOF management purposes (see subsection $\mathrm{D}$ below), separate fiscal-monitoring units were set up to collect the necessary data. Second, there was often a disconnect between the budget execution and budget preparation: in some cases, warrants were issued by the Budget Department without knowing the extent of previous utilization, because the AG's data was not produced on time.

\section{Powers and accountability of the MOF versus spending ministries (SMs)}

Under the inherited system, financial control was largely assigned to SMs. The "Accounting Officer" (AO)-generally the head of the SM-had the authority to make expenditure commitments against their budget appropriations without reference to MOF. A decentralization of powers is appropriate provided there is adequate accountability. In most Anglophone African countries, accountability at the SM level has been deficient. Accountability has many aspects, including disclosure requirements and publication (e.g., fiscal data, procurement proceedings). A survey found that public works and construction were widely perceived to be the sectors most riddled by corruption, followed closely by the defense sector. ${ }^{25}$

Partly for these reasons, some countries re-centralized the check-writing function back to the MOF (e.g., Tanzania). In others, SMs are still responsible for check issuance (e.g., Malawi, Zambia). The former facilitates the recording and control of payments, whereas it can led to lags between reception of payment vouchers and actual payment. The SMs can see the payment stage as the AG's problem, not theirs; they therefore continue to submit payment requests to the $A G$, provided they remain within annual appropriations. In general, in many countries, the recording, monitoring, and centralization of payments has been very weak. This reflects generalized weakness of the internal audit function (see subsection D below), which increases the scope for collusion between suppliers and SM managers.

\section{Ineffective external audit}

The external audit function has also been malfunctioning. After independence, AuditorGeneral's Offices (AuGOs) were created as an executive branch agency to perform audits, mainly for compliance purposes. ${ }^{26}$ AuGOs were often inadequately staffed and not provided

\footnotetext{
${ }^{24}$ Fragmentation has been identified as one reason for poor budget performance in OECD countries (e.g., Kontopoulus and Perotti (1999)). However, these studies examined fragmentation in Parliament and in Cabinet. In Africa, could be more useful to examine the extent of fragmentation within the MOF.

${ }^{25}$ See Pope and Vogl (2000).

${ }^{26}$ Modern external audit offices are watchdog institutions reporting primarily to the Legislative branch. They usually have a separate legal framework. In contrast, Financial Management and Audit Acts (joint legal frameworks) have governed, and continue to govern, most Anglophone African countries.
} 
with financial and operational independence. Moreover, due to delays by the accountant general's office in producing annual accounts, the auditor general's basic task of auditing annual accounts and presenting a report to the public accounts committee of Parliament was sometimes long delayed, and thus the auditor's basic tasks were undermined ${ }^{27}$ Even more serious, when the auditor general's reports became available, their recommendations were not implemented, often being ignored completely. This was partly because the strong role of Parliament of the inherited system had been stultified. Thus, one avenue by which compliance and transparency in budget execution could have been improved was closed.

\section{Weakness in Budget Preparation}

\section{Multi-year planning but absence of link to the annual budget}

Inspired by developments in both Western European countries and centrally-planned economies, after independence many African countries prepared long-term development plans, in parallel with the annual budget. ${ }^{28}$ It became clear, however, that full implementation of multiyear plans was impossible, as first- or second-year plan outcomes differed greatly from multiyear plan objectives. This was because spending Ministers were given considerable autonomy in preparing their annual budget estimates, and could consider the Plan figures as optional (see Green (1965)). Thus, any envisaged links between planning and annual budgets were quickly snapped: Planning was perceived to be part of the problem, not the solution (see Chapter 9 of Caiden and Wildasky (1974)). As a consequence, the multi-year recurrent cost implications of investment expenditure were not fully assessed. It was not until the 1990s that Medium-Term Expenditure Frameworks (MTEFs) began to be developed (e.g., Ghana, Malawi, Uganda). These allow for reviews of expenditure programs and encourage more open debate on budget priorities. Although MTEFs can, in principle, prevent a strong executive from enforcing its own perceptions of national budgetary priorities, their effectiveness in reorienting cash allocations away from unproductive expenditures and toward the most urgent social needs, is yet to be fully proven. In the countries where MTEFs have been developed, the outcome for the first year is often very different from that budgeted, implying that outer-year projections have to be re-worked intensively.

\section{Unrealistic annual budget projections}

The tendency toward optimism in projecting revenues, ${ }^{29}$ was attributable in part to institutional weaknesses, and in part because optimistic assumptions were made for economic

${ }^{27}$ These problems continue to be severe in some countries. For example, in The Gambia until 2001, the last audited annual accounts related to the 1990/91 fiscal year.

${ }^{28}$ The United Kingdom itself embraced multi-year plans in the 1960 s.

${ }^{29}$ Actual revenue was below targeted revenue by $1 / 2$ percent of GDP on average for the 8 countries shown in Table 12 of IMF (1998). 
growth and/or improvements in tax and customs administration. With actual revenues falling short of budgeted revenues, the authorities' ability to meet aggregate expenditure targets was undermined.

In these circumstances, there were large gaps between available resources and expenditure programs. Although reviewed, there is still a need for effective reductions in unproductive or excess outlays. At the same time, desirable new policies, such as the introduction of universal primary education, or enhanced provision of basic health care, added to spending in excess of revenues. Thus, instead of reforming expenditure policies and reducing the dimensions of government, line ministries often continued to commit unsustainable expenditures.

On top of this, some outlays were under-funded in the budget. One example is interest on government debt. A second example is government utility payments (telephone, electricity, water and rents). Spending ministries often did not know the quantities (hours of telephone use, Kwh of electricity, etc.) consumed. Even when known, ministries were unable (and unwilling) to control these expenditures, believing that the government would eventually pay the bill of the utility company, which was usually government-owned.

Since actual expenditures often differed markedly from appropriations, the budget preparation process was not taken seriously by SMs. Even when the MOF made efforts to introduce more realism into budget projections, spending ministries were skeptical. With a low degree of cooperation between the MOF and spending ministries, a vicious circle of unreformed budget policies, under-funded government programs, and fragmented budget execution processes developed.

\section{Frequent supplementary budgets}

In principle, supplementary budgets were to be submitted to parliament when there was a major change in the macroeconomic framework and urgent expenditures had to be met. Ideally, new revenue-raising measures should have financed any supplementary expenditures. In practice, overspending cumulated during the year, and towards year-end, by approving supplementary budgets, weak parliament's legitimized overspending. In the absence of new revenues, the fiscal deficit widened, being financed either through unforeseen borrowing or by an accumulation of payment arrears, both of which jeopardized attaining macroeconomic targets. With supplementary budgets not fully considered by Parliament, undue financial power was conveyed to the MOF. In particular, certain spending agencies were favored, thereby undermining the role of the legislature in allocating government resources. Additionally, the voices of less powerful ministries and citizens were not heard.

\section{Non-transparent budgets and loss of significance of the budget document}

In some countries, quasi-fiscal activities abounded. These included subsidized lending to stateowned agricultural marketing boards through the banking system and implicit subsidies: to public enterprises, tax expenditures, non-reimbursed on-lent loans, equity participation and capital injections. These were seldom recorded. 
These practices accentuated the loss of significance of the budget document, which should be the sole source of analysis of government allocation policies. In addition, although improvements were made in presenting the budget, the quality of budget documents was low. In particular, the legislative branch was not provided with adequate documentation on the rationale for votes, the impact of changes in budgetary policies in the coming fiscal year, and any reprioritization in outlays.

\section{Shortcomings in Budget Execution}

\section{Lack of recording and monitoring of expenditure commitments}

According to financial instructions to AOs, expenditure commitments should be recorded in the accounting registries ("Vote books") of spending ministries (SMs). In turn, these should be reported to the MOF for consolidation. In practice, SMs' vote books were usually incomplete and the MOF was lax in reconciling the AG's records with SMs' vote books. As a result, the general ledger of government transactions was incomplete and often out of date. Moreover, the MOF was unable to monitor expenditure commitments, a necessary prerequisite for controlling expenditures.

With weak accounting and poor coordination between budget and accounting divisions of SMs, expenditure commitments were made without reference to cash availability. In some instances, commitments were within the approved budget, but in other instances, commitments were even above the annual approved budget - symptomatic of a lack of disciple. In both cases, payment arrears accumulated.

\section{Arrears accumulation}

Many Anglophone African governments have experienced, or are still experiencing, difficulties in paying invoices. In cases were expenditure arrears have been measured, their size has varied across time and countries (Table 1). Arrears are often not measured accurately because accounting systems are incapable of recording liabilities as they are incurred.

Being aware that the government was not paying its bills in a timely fashion, suppliers of goods and services over-invoiced government to cover their impending losses due to late settlement. Non-payment by government also resulted in some suppliers requiring government to pay in cash upfront, in contravention to financial instructions. In some cases, enterprises stopped paying taxes; at a latter point in time, were offset against entreprises' obligations to government, the government's obligations to enterprises. 
Table. Domestic Expenditure Arrears in Selected Countries, 1999-2001 ${ }^{30}$

\begin{tabular}{|c|c|c|}
\hline Country & $\begin{array}{l}\text { Stock of Arrear } \\
\text { (percent of } G D P\end{array}$ & Date \\
\hline Ghand & Wxym & Decenber 1999 \\
\hline Kenya & 27 & Why \\
\hline Malawim & (M) & October 1999 \\
\hline Manzany & WW & March 2000 \\
\hline Uganda & Who & He, 1909 \\
\hline andinia & 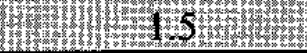 & Docenoer 1999 \\
\hline
\end{tabular}

Source: IMF, based on censuses/audits conducted by national authorities. No reliable data are available for The Gambia, Nigeria and Zimbabwe.

Monitoring payment arrears proved to be very difficult. For arrears of salaries and debt servicing, where payment due dates were clearly known and recorded, data were generally obtainable. In contrast, for suppliers' arrears, the MOF was unaware of all cases where goods had been ordered, received and verified but no documentation had been processed or payment vouchers had not been raised by the SMs. In some countries, surveys of expenditure arrears were conducted. However, they were often either incomplete or were not verified against actual deliveries. In some cases, audits revealed fictitious invoices. Although useful, surveys and audits of arrears are palliatives for improved accounting systems.

\section{Proliferation of bank accounts}

SMs often maintained many government bank accounts. In countries where check-issuance was decentralized to SMs, expenditure accounts were opened for different spending categories. For foreign-financed expenditures, donors insisted on opening separate bank accounts for their project disbursements. Concerning revenue accounts, SMs opened spending accounts in banks, crediting them with self-raised revenues or transfers from the consolidated fund. This resulted in idle cash balances that were inaccessible to the MOF for cash management purposes.

Expenditure and revenue accounts were held in both the central bank and commercial banks (and their branches). In some countries, the MOF did not know the number of government bank accounts, nor the amounts transiting in and out on a monthly basis. Accounts for belowthe-line (BTL) transactions (see Appendix I) proliferated, dormant accounts were not closed and treasury staff was unsure of what transactions should be posted to each account. Also, for revenue and expenditure accounts, bank reconciliation was not conducted at prescribed intervals.

\footnotetext{
${ }^{30}$ For Uganda, expenditure arrears have fallen substantially since the shown date. In other countries, increases or decreases in arrears may have occurred.
} 


\section{Unreliable fiscal reports and annual accounts}

Abnormal delays were often experienced in reporting fiscal data. Monthly expenditure returns to the accountant general's office from SMs, sub-treasuries and overseas missions were often late, making it difficult to obtain timely aggregate expenditure data. Similar delays arose for revenue returns from the revenue-collecting agencies. For nontax revenues, SMs preferred not to disclose the amounts in these accounts. Although donor grants assumed increasing importance in financing government investment expenditures, the spending from development projects was usually recorded partially, at best.

The basis of good fiscal reporting is a core accounting system with full coverage of every transaction and timely provision of quality data. Because of the above-mentioned problems, aggregate fiscal monitoring tables-showing monthly revenues, expenditures, and financing-became unreliable. Often there were large discrepancies between fiscal and monetary data. The poor accounting records, together with lack of materials and qualified staff, resulted in delays in preparing Annual Accounts.

\section{Weak internal audit}

The process controls of the inherited system - the collection and release of funds, monitoring, and payment controls - were only partly implemented. Internal audit divisions were set upgenerally in the accountant general's office-and staff was posted to ministries. However besides lacking adequate training, internal auditors were not encouraged to forcibly impose financial regulations. Furthermore, there was only limited adaptation of the inherited expenditure control system to expand the range of techniques for internal control and audit.

\section{Excessive reliance on cash rationing, resulting in unsatisfactory service delivery}

In the $1990 \mathrm{~s}$, several countries developed cash-rationing systems to deal with persistent cash shortages. Such systems were expedients to allow objectives for net bank credit to government to be met. However, the underlying reasons for the cash shortages-including unrealistic budgets, extrabudgetary expenditures, and lack of cash management systems (see below) - were not addressed directly. The unavailability of essential data, the lack of clear criteria for expenditure prioritization, and political pressure for "urgent" or "unforeseen" expenditures, all prevented the MOF from making objective decisions on the cash limits for each SM. Discretionary decisions were often made by a few individuals in one department of the MOF. This resulted in sharp fluctuations in SMs' monthly funding. In addition, the cash-rationing systems provided scope for misdirecting government monies. In view of the costs of maintaining cash-rationing mechanisms, some have argued for their relaxation. ${ }^{31}$

\footnotetext{
31 For example, for Zambia, see Adam and Bevan (1997).
} 
The rationing of available cash was most severely felt on nonsalary expenditures. With under-funding of outlays, there was a substantial disruption to service delivery. As examples, hospitals were without medicine, schools without textbooks, and vehicles without fuel and repair. Yet the medical staff, teachers and drivers were usually still paid, ${ }^{32}$ even though their work was under-productive. Similarly, with cutbacks in funding for domestically-financed investment, development projects were delayed; the foreign-financed component was sometimes held up until domestic counterpart funds were provided.

\section{Absence of effective cash management and financial planning}

In the U.K., cash inflows and outflows are now projected on a daily basis, in order to determine short-term financing gaps and the need for temporary borrowing (or treasury bond redemptions) in the weeks/months ahead. Such cash planning did not develop in Anglophone African countries: either budget deficits were allowed to burgeon (up until the 1990s, this was generally financed by direct borrowing from the Central Bank $)^{33}$, or available cash to spending agencies was rationed on an ad hoc basis. To change cash-rationing systems to modern cash and debt management systems, improvements in basic accounting and expansion of computerization of budget execution is required.

\section{E. Failure to Impose Budget Discipline}

A major problem in many Anglophone African countries is that the laws and regulations are often not complied with. Although accounting officers are personally and pecuniarily responsible for ensuring expenditure control of their votes, they are usually not sanctioned when they fail to abide by administrative instructions. Moreover, when the "center" attempted to exert control over expenditure, innovative ways were found to circumvent financial regulations. Some examples follow.

\section{Noncompliance with financial laws and regulations ${ }^{34}$}

- Increase in off-budget activities. With limited or no budgetary oversight role played by Parliament, extrabudgetary activity flourished, particularly in countries with military governments. In Nigeria, for example, until the recent restoration of democracy,

\footnotetext{
${ }^{32}$ In some countries, teachers and health care employees, especially those in rural areas, suffered considerable delays in payment of salaries.

${ }^{33}$ More recently, budget deficits have been financed by treasury bills in most countries, with most of these treasury bills being held by banks and other financial institutions.

${ }^{34}$ Lack of transparency, accountability and enforcement of existing rules are stressed in Campos and Pradhan (1996), who included Ghana, Malawi and Uganda in their survey.
} 
considerable spending was financed by oil revenues entirely outside the budget process, and the movement of funds through various bank accounts was not tracked.

- Weaker control over special funds. Using earmarked revenues, some countries established special funds (e.g., road funds). These were usually not subject to the same control, reporting and accountability procedures as normal budget outlays.

- Withholding of nontax revenues. In most countries, certain "retention" rules applied to SMs that collect fees. Although some fees were allowed to be retained, a portion should be transferred to the consolidated fund. In practice, a higher-than-authorized share of nontax revenues were retained by the SMs and used for their own expenditures.

- Cash limits were not respected. Although "cash budget" expenditures limits differed substantially from budget appropriations, SMs considered they had the right to spend "their" approved annual appropriations. This problem was accentuated in countries that had not issued clear treasury instructions to abide by the cash limits.

- $\quad$ Failure to report. Although AOs' responsibilities were generally laid out in appointment letters, including the need to provide regular reports to the MOF, in practice AOs did not ensure that accounting staff prepared expenditure reports for the MOF according to prescribed reporting standards. Since AOs were often appointed by the presidency, there was often reluctance by the MOF to take affirmative action to enforce discipline.

\section{Innovative ways for circumventing expenditure controls}

- $\quad$ Promissory notes (PNs). ${ }^{35}$ Instead of making payment, PNs were issued to suppliers in some countries. When commercial banks rediscounted PNs to the central bank there was a direct impact on base money, thereby making it more difficult for the central bank to attain its inflation-control objectives. Also, "payment" by PN issuance usually by-passed public procurement rules: the recipients of PNs were government suppliers with direct access to key players in government. Expenditure control was lost in cases when PNs were used to finance goods or services not included in the budget (in some cases, military purchases were financed in this way).

- Suspense accounts and advance payments were used excessively. In principle, advance accounts for travel, contract start-ups, etc., are acceptable practices, provided their scope is limited and the rules for spending from such accounts are enforced. However, in some countries an excessive number of suspense and advance accounts were created to speed up certain payments and substantial balances accumulated. Drawdowns were recorded as "unallocated expenditure," making it more difficult to

\footnotetext{
${ }^{35}$ Promissory notes are government paper issued by MOFs. The arrangements govcrning the interest rates and redemption possibilities normally may differ from one issue to another. Nonetheless, commercial banks view them as quasi treasury bills.
} 
monitor actual expenditure developments during the course of the year. Accounting rules require that accounts are closed at year-end; instead, balances were carried over into the next year fiscal year, thereby distorting the accuracy of the final annual accounts.

\section{Corruption in budget management}

Besides indiscipline, some countries also have witnessed corruption in the expenditure process. This has shown up, for example, in government contracts being awarded after bribes have been paid, and by suppliers of goods or services to government "arranging" payment with the MOF officials who made the cash allocation decisions. "Ghost" government workers have knowingly been retained on civil servant payrolls. Although some countries are now tackling corruption head-on, for anti-corruption measures to succeed, all levels of the Executive branch need to be committed to impose discipline in the budget process. For example, decisions for off-budget spending contrary to the Financial Regulations may be made by authorities higher than AOs. AOs usually have little choice but to implement any directives (since those producing such directives usually have the power to terminate AOs employment contracts), thereby perpetuating budgetary practices inconsistent with sound budget control. Worse, they may even be rewarded for implementing the directives, thereby perpetuating financial indiscipline.

\section{Concluding Remarks and Orientation of Future Reforms}

The inherited British budgeting system was based on strong control by the Legislative branch. At the same time, the Executive branch established an adequate regulatory framework. Strong institutions were required for the system to function. However, in anglophone Africa, the required institutional capacity was weak. In particular, Parliament - if it existed-did not participate fully in debating the executive's proposed budget. Also, the scope for the AuditorGeneral's Office to monitor and recommend changes to the system was severely limited. Within the executive, the Minister/Ministry of Finance and Permanent Secretaries of spending ministries were often under the control of a strong presidency.

The centralization of strong powers in the executive has not been associated with the promotion of fiscal discipline. On the contrary, in many Anglophone African countries, discipline, accountability and transparency is lacking at the various stages of the budget process. Although in several countries the executive is now attempting to ensure that cash expenditures are more in line with total resource availability, this is being attained at the expense of budget outcomes quite different in size and sectoral allocation than that in Parliament's budget. Some ministries (e.g., Defense, State House) have, at the budget execution stage, managed to obtain

more than their fair share of available cash. As a result, many spending ministries have lost faith in the budget process.

Some features of the inherited British budgeting system sowed the seeds for today's PEM problems, including: dual budgeting; extrabudgetary funds; classification systems that hinder economic analysis; and inappropriate use of public enterprises for budgetary purposes. However, in the U.K. the 1961 Plowden Commission made recommendations for addressing 
systemic weakness, most of which were introduced in the 1960s. In contrast, most of the Plowdon Commission's recommendations are still relevant for most Anglophone African countries.

PEM systems were also influenced by multilateral and bilateral donors. The IMF encouraged the implementation of cash rationing schemes in the $1990 \mathrm{~s}$, as they allowed countries to attain macro-stability objectives. However, this was at the expense of ineffective delivery of public services. Under the influence of the World Bank and other donors, dual budgeting was not only tolerated, but actively promoted-by PIPs at the budget preparation stage and by separate donor accounts outside the consolidated fund for donor-financed development expenditures. Although the international community provided technical assistance, reforms in PEM have not always been institutionalized.

The most conspicuous problems in operating PEM systems have been self-generated, including: little adaptation of institutional arrangments, poor budget preparation, ineffective budget execution and audit arrangements. Reforms in these areas will require that government institutions perform their fundamental roles, in accordance with financial regulations.

Technical changes in budget preparation and budget execution are needed. It is particularly important to get the basics right. ${ }^{36}$ Concerning budget preparation, key actions include: introducing greater realism into annual budget projections, ending dual budgeting, extending budget coverage to include all off-budget activities, setting the budget in a medium-term framework, and eliminating abusive use of supplementary budgets. For budget implementation, the most pressing short-term needs include: monitoring and controlling expenditure commitments and arrears, strengthening internal controls within spending ministries, reducing reliance on arbitrarily-determined cash controls, and introducing and/or improving cash and debt management. Above all, accounting systems and fiscal reporting need to be improved. This would be facilitated by developing integrated financial management information systems (IFMISs), provided there is appropriate conceptual design at the outset and the sustainability of IFMISs is secured.

The speed and sequencing of the reforms need to be adapted to individual country circumstances. In this context, care needs to be exercised to avoid a "high-technology" approach, especially if "fundamentals" are lacking. For example, developing IFMISs or medium-term expenditure frameworks (MTEFs) should not proceed until countries rectify inadequate accounting practices (e.g., where accounts are not reconciled, resulting in unreliable fiscal data).

The strong powers accorded to the executive's central institutions could be used more effectively, including ensuring that: existing (or revamped) public finance laws and

${ }^{36}$ It is beyond the scope of this paper to discuss why reforms in OECD should not be quickly adopted in African countries. For discussion, see Bale and Dale (1998) and Shick (1998). 
administrative regulations are adhered to; those with delegated budget authority effectively carry out their responsibilities; and comprehensive and quality reports of budget developments are available to the public in a timely manner. This will require better dialogue with spending ministries, and upgrading staff and materials for managing budget systems. It may also require restructuring the Ministry of Finance, to distinguish clearly the roles and responsibilities of various departments. Strong leadership and commitment to reform are essential.

Perhaps the most important prerequisite is to establish a firm commitment to budget discipline. In this context, the capacity of existing institutional arrangements to introduce, maintain, and manage reoriented systems deserves re-examination. On the side of the legislature, democratically-elected Parliaments may have to play a more prominent role in debating budget policies and the auditor-general's office should be given more scope for improving the effectiveness of budgetary procedures and policies.

More generally, changes in institutional arrangements for securing aggregate fiscal discipline and for reversing the misalignment between budget appropriations and cash budget outcomes will be ineffective unless they are accompanied by measures to enhance accountability and transparency at all levels of the budget process. In particular, sanctions should be applied on those contravening regulations, with the results being rendered public. Strong political will is required to re-impose the rule of law and counter corruption, which is not confined solely to budget management, but is a generalized problem in many Anglophone African countries. 


\section{THE INHERITED BRITISH BUDGETING SYSTEM}

This appendix describes key features of the budgeting system used in the United Kingdom in the late 1950s. ${ }^{37}$

The budget preparation cycle usually began on October 1 when the Treasury sent out its Estimates Circular asking spending Departments to submit estimates by December 1 . The "Supply" division of Treasury scrutinized the estimates to see whether they were in conformity with treasury instructions, working in close collaboration with the Establishment division to ensure consistency with the salary estimates.

Once agreement was reached at technical level, the annual budget approval process followed four steps: (i) the executive finalized its Estimates; (ii) after Committee of Supply deliberations, the lower house of Parliament granted the sums demanded (or possibly reduced them); (iii) after deliberation by the Ways and Means Committee, the lower House sanctioned agreed expenditures from the Consolidated Fund; and (iv) the Appropriation Act was assented to by both Houses of Parliament. Under a 1706 Standing Order, only the executive could initiate spending proposals; Parliament could not increase the executive's proposed appropriations.

During the course of the year, any department could embark on new policies or alter the terms of existing policies. The Minister concerned could submit his proposal directly to Cabinet, but due notice had to be first given to the Treasury to ensure that the financial implications of the proposals were properly costed prior to a Cabinet decision.

Although the Budget had begun to take into consideration the wider economic setting, including the need for fiscal policy to contribute to control inflation, the budget was formulated along traditional lines, divorced from the macroeconomic framework. The budget was essentially a "current revenue/expenditure" table and a financing table (see Appendix Table). The first account - the "above-the-line" (ATL) account-showed (i) the revenue of Central Government from taxes and other current income, and (ii) the current expenditure to be met out of that revenue, consisting of statutory expenditures (for which annual parliamentary approval was not required) and "Supply" estimates, which showed the annual expenditures "voted" to spending ministries. The second table-the "below-the-line" (BTL) account was sometimes called the "capital account". However, this term was misleading as many of the transactions in the BTL account were of a financing nature, although some were capital expenditures.

Government debt servicing and overall deficit financing was intransparent. BTL payments consisted of debt interest not already included ATL and loans to non-central government entities (e.g., local authorites, nationalized industries). Interest payments on the National Debt appeared in both the ATL and the BTL accounts: in the ATL account, those of central

\footnotetext{
${ }^{37}$ The authors are indebted to Brittain (1959) for much of the material in this Appendix.
} 
government were shown, whereas interest made by Treasury on behalf of local governments or nationalized enterprises were shown BTL. The other main receipt items of the BTL accounts were repayments of past advances made to local authorities and nationalized industries. Finally, the BTL account was always balanced by transferring any surplus from the ATL and/or net borrowing. This was not broken down into gross new borrowings and repayments of existing government debt.

The budget's role as a countercyclical instrument dominated government borrowing decisions in the 1950s. If inflation control was perceived to be the priority, then taxation and expenditure policies were changed to dampen aggregate demand, with the ATL account always being in surplus. In contrast, if the prevailing economic problem was one of counteracting deflation, then pump-priming, via a deficit of the ATL, was promoted.

The roots of three-year budgeting were implanted in the procedures for preparing the British budget. For non-defence estimates, just before the beginning of budget year $\mathrm{X}$ spending Departments provided the Treasury with forecasts of spending in years $(X+1)$ and $(\mathrm{X}+2)$. Although these estimates were revised every six months, they were not made public.

Supplementary budgets could be adopted by Parliament to modify budget appropriations if there were emerging expenditure overruns during the course of the year. Virement--the transfer of expenditure from one line-item to another-was permitted and required only the Ministry of Finance (MOF) authority. However, virement between salary and non-salary expenditures, or between spending departments, needed Parliamentary approval.

At the end of the fiscal year, unused annual appropriations lapsed and had to be reappropriated in the following year's budget. Since some spending Departments raised their own revenue ("appropriations-in-aid"), Parliament approved appropriations for gross expenditures and those net of any appropriation-in-aid. If a spending Department raised more money through fees than appropriated, the surplus had to be returned to the Consolidated Fund at the end of the fiscal year, i.e., the revenues could not be retained by the spending Department.

Parliament recognized that, on occasions, the Government would need to incur urgent expenditures that could not wait until a Supplementary Budget appropriated new funds. It therefore set up by statute the Civil Contingencies Fund with a permanent capital to enable the MOF to make advances. Such Funds are included in most Anglophone African countries' legislative framework, including the Constitution in some cases.

Following the adoption of the annual budget by the legislative branch, various administrative steps were required before budget execution could formally begin. First, the MOF had to apply to the Comptroller and Auditor-General (C\&AG) for a credit from the Bank of England for the amounts appropriated. Once obtained, the Treasury issued "Supply Votes" to the Paymaster General (PG). Since the PG was usually a Minister with non-financial duties, he generally delegated Exchequer matters to his deputy-the Assistant Paymaster General-who was a permanent civil servant. In Anglophone Africa, the Accountant General (AG) now 
generally plays this role. When spending ministries needed money, the PG applied to the Treasury for funds from the central bank account, from which all departmental payments were made. The PG was to ensure that accounts (ledgers) were kept showing the amounts of the Votes, and the payments made out of those Votes.

\section{Spending Ministries' "accounting officers" (AOs) were the key players for implementing} the annual budget. They were usually the Permanent Secretaries (PSs) of spending ministries, whose main responsibilities were to:

- $\quad$ Prepare the ministry's "Vote", which specified the annual cost of policies, as reflected in the estimates of expenditure by Head, sub-Head, and Item;

- Execute the budget for his/her Ministry: charge promptly to the department's accounts all disbursements of public funds, as well as any revenues received by the department; and ensure the maintenance of all books, records, vouchers and cash in his/her charge. In particular, AOs were called upon to ensure the recording of warrant issuance-the legal authority to spend a certain amount of budgeted appropriations in a given time period; commitments-spending departments' expenditure liabilities; and cash outlayspayments, following cash being made available by the Treasury.

- Ensure the regularity of all payments authorized by his/her department, and that all funds entrusted to him were applied only for the purpose intended by Parliament;

- Accept personal and pecuniary liability to the Legislature through Parliament's Public Accounts Committee (PAC) for the administration of the Vote under his/her control.

The Treasury letters of appointment of Accounting Officers were important documents. These not only laid out the responsibilities for regularity and propriety, but they put on record the importance of financial control. Importantly, appointment letters typically specified sanctions for non-compliance.

There were rules for preventing the accumulation of expenditure arrears, namely that: (i) spending ministries submitted monthly accounting records, together with supporting documents, to the Comptroller and Auditor-General; ${ }^{38}$ (ii) each spending ministry provided to the MOF before the end of the third quarter of each year, an estimate of the expected cash spending for the year as a whole, showing which sub-heads would be over- or under-spent; and (iii) government financial liabilities must be met in the year in which they are due. These requirements implied that spending ministries had to be vigilant in recording expenditure commitments. Commitment control was an administrative tool used to meet Parliament's demands for accountability for cash actually spent.

${ }^{38}$ In larger spending Departments, officers of the C\&AG's office sat in ministries conducting audits currently. 


\section{Appendix I Table: United Kingdom Budget, Late 1950s}

In billions of pounds

A. Above The Line (ATL) account

Revenue 5.4

1 Inland Revenue (mainly income tax)

2 Customs and Excises

3 Other $1 /$

Current expenditure

1 Consolidated Fund Service 2/

of which: debt interest $3 /$

2 Supply 4/

Defence

Civil

Balance (surplus of current transactions)

\section{B. Below The Line (BTL) Account}

\begin{tabular}{|lc|}
\hline Receipts & 0.9 \\
1 Interest outside Budget & 0.2 \\
2 Repayments of past advances & 0.1 \\
3 Net sum to be borrowed, or surplus from ATL account 5/ & 0.6 \\
Payments & 0.9 \\
1 Interest outside Budget & 0.2 \\
2 Advances & 0.7 \\
$\quad$ of which: to nationalized industries & 0.5 \\
Balance & 0 \\
\hline
\end{tabular}

1/ Includes motor vehicle duties, net Post Office revenue, and other nontax revenue.

2/ Consolidated Fund Services are, by statute, authorized once and for all.

3/ This does not represent all interest on the National Debt.

4/ "Supply" are expenditures voted annually by Parliament.

5 / In this budget, $0.4 \mathrm{~b}$. pounds would be obtained from ATL and $0.2 \mathrm{~b}$. borrowed.

Source: Brittain (1959), pages 45-48. 


\section{REFERENCES}

Adam, C. S. and Bevan, D.L., (1997), "Fiscal Restraint and the Cash Budget in Zambia," Centre for the Study of African Economies, University of Oxford, United Kingdom, January.

Alesina, A., and Perotti, R., (1996), "Budget Deficits and Budget Institutions," IMF working paper WP/96/52, May, Washington, D.C.

Bale, B. and Dale, T., 1998, Public Sector Reform in New Zealand and Its Relevance to Developing Countries, World Bank Research Observer, Vol. 13, No. 1, February, World Bank, Washington, D.C.

Brittain, Herbert, Sir, 1959, "The British Budgetary System," Ruskin House, George Allen \& Unwin Ltd., London, United Kingdom.

Caiden, N, and Wildavsky, A., 1974, "Planning and Budgeting in Poor Countries," John Wiley and Sons, New York.

Campos, E., and Pradhan, S., 1996, "The Impact of Budgetary Institutions on Expenditure Outcomes," World Bank.

Clarke, Sir Richard, 1978, "Public Expenditure, Management and Control," Macmillan Press, London.

Green, R., 1965, “Four African Development Plans: Ghana, Kenya, Nigeria, and Tanzania,” Journal of African Modern Studies, 3, 2.

Heller, P.S., and Aghevli, J.E., 1985, "The Recurrent Cost Problem: An International Overview," in (ed.) J. Howell Recurrent Costs in Agricultural Development, Overseas Development Institute, London

Hoover, D., and McPherson, M., 1999, "Capacity Building in the Ministry of Finance, Zambia," Development Discussion Paper No. 704, Harvard Institute for International Development, Harvard University, United States.

International Monetary Fund, 1997, "The ESAF at Ten Years: Economic Adjustment in LowIncome Countries," IMF Occasional Paper No. 156, December, Washington, D.C.

International Monetary Fund, 1998, "Fiscal Reforms in Low-Income Countries: Experience Under IMF-Supported Programs," IMF Occasional Paper No. 160, March, Washington, D.C.

International Monetary Fund, 2000, Draft revised Manual on Government Financial Statistics, available on IMF website, http://www.imf.org, Washington, D.C. 
Lienert, I. and Modi, J, 1997, "A decade of civil service reform in sub-Saharan Africa," IMF working paper WP/97/179, December, Washington, D.C.

Nunberg, B., 1997, "Re-Thinking Civil Service Reform: An Agenda for Smart Government," Poverty and Social Policy Department, World Bank, Washington, D.C., June 30.

Plowden, Lord, 1961, "Control of Public Expenditure," Cmnd. 1432, report presented to U.K. Parliament, Her Majesty's Stationary Office, London, July.

Pope, J., and Vogl, F., 2000. "Making Anticorruption Agencies More Effective," article in Finance and Development, Vol. 37, No. 2, International Monetary Fund, Washington, D.C., June.

Premchand, A.,1983, "Government Budgeting and Expenditure Controls: Theory and Practice," IMF, Washington D.C.

Shick, A., 1998, "Why Most Developing Countries Should Not Try New Zealand Reforms," paper presented to Poverty Reduction and Economic Management Seminar Series, Public Sector Group, World Bank, Washington, D.C., March 10.

Skilling, D., 2001, "The Political Economy of Public Debt Accumulation in OECD countries since 1960," draft based on PhD thesis (forthcoming), Harvard University, USA.

Stevens, M., 1994, "Public Expenditure and Civil Service Reform in Tanzania", Chapter 4 of "Rehabilitating Government: Pay and Employment Reform in Africa," D. Lindauer and B. Nunberg (eds), World Bank Regional And Sectoral Studies, World Bank, Washington, D.C.

von Hagen, J., and Harden, I., (1996), "Budget Processes and Commitment to Fiscal Discipline," IMF working paper WP/96/78, July, Washington, D.C.

World Bank, 1998, "Public Expenditure Management Handbook," World Bank, Washington, D.C. 